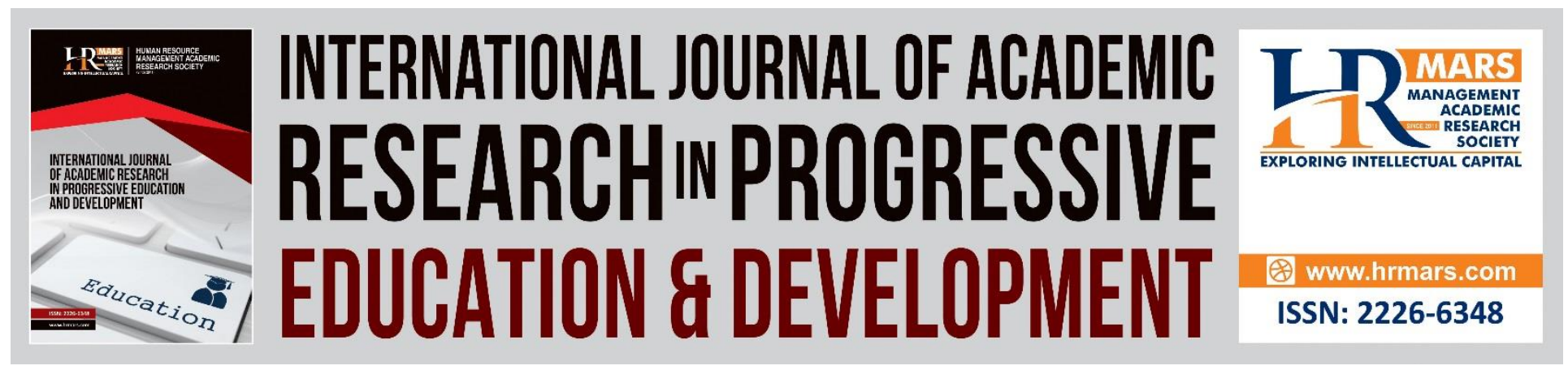

\title{
Is Online Training Program Effective for Undergraduates' Learning During COVID 19? A Quasi-experimental Study Using the Malaysian Sample
}

Siti Fardaniah Abdul Aziz, Rusyda Helma Mohd, Mohd Nasir Selamat, \& Nik Hairi Omar

To Link this Article: http://dx.doi.org/10.6007/IJARPED/v10-i2/9630

DOI:10.6007/IJARPED/v10-i2/9630

Received: 23 February 2021, Revised: 20 March 2021, Accepted: 07 April 2021

Published Online: 27 April 2021

In-Text Citation: (Aziz et al., 2021)

To Cite this Article: Aziz, S. F. A., Mohd, R. H., Selamat, M. N., \& Omar, N. H. (2021). Is Online Training Program Effective for Undergraduates' Learning During COVID 19? A Quasi-experimental Study Using the Malaysian Sample. International Journal of Academic Research in Progressive Education and Development, 10(2), 201219.

Copyright: (C) 2021 The Author(s)

Published by Human Resource Management Academic Research Society (www.hrmars.com)

This article is published under the Creative Commons Attribution (CC BY 4.0) license. Anyone may reproduce, distribute, translate and create derivative works of this article (for both commercial and non-commercial purposes), subject to full attribution to the original publication and authors. The full terms of this license may be seen

at: http://creativecommons.org/licences/by/4.0/legalcode

Vol. 10(2) 2021, Pg. 201 - 219

http://hrmars.com/index.php/pages/detail/IJARPED

JOURNAL HOMEPAGE

Full Terms \& Conditions of access and use can be found at http://hrmars.com/index.php/pages/detail/publication-ethics 


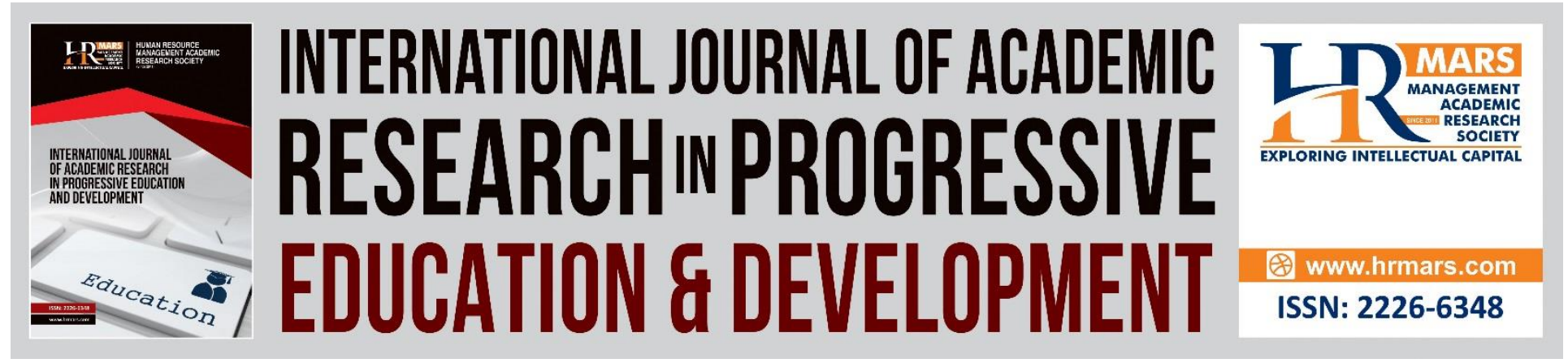

\title{
Is Online Training Program Effective for Undergraduates' Learning During COVID 19? A Quasi-experimental Study Using the Malaysian Sample
}

\section{Siti Fardaniah Abdul Aziz, Rusyda Helma Mohd, Mohd Nasir Selamat, \& Nik Hairi Omar}

Human Development Program, Psychology \& Human Well-Being Research Centre, Faculty of Social Science \& Humanities, Universiti Kebangsaan Malaysia, Malaysia

Email: rusyda_h@ukm.edu.my

\begin{abstract}
Pandemic COVID 19 has changed the world's communication medium into online communication to prevent the spread of pandemic since the end of 2019; this has also impacted students' learning either at primary, secondary, college or university level. Since online communication was mandated as a medium to deliver learning, many researchers have started to determine the effectiveness of online learning for formal educational setting. However, research reported the effectiveness of students' online learning in informal setting, such as online training program was very limited. Hence, this article aims to report the effectiveness of online training program among undergraduates in Malaysia using a quasi-experimental design. Three different training programs were conducted during December 2020 among undergraduates at University Kebangsaan Malaysia based on open registration; there were 52 participants in total. Participants were asked to answer a questionnaire before and after the completion of training program using google form to determine the achievement of training objectives. General Training Effectiveness Scale was adapted and modified accordingly to each training program's objective to measure learning performance as perceived by participants; data were analyzed using paired sample t-test and one-way ANOVA in SPSS software. Findings indicated a significant mean difference between scores as measured before and after training completion, and insignificant difference between all the three training programs indicating that online training among undergraduates is effective regardless different training objectives. In conclusion, it is verified that online learning is beneficial to replace traditional classroom for informal education during the pandemic, such as training program among undergraduates. Hence, it should be used for knowledge acquisition,
\end{abstract}


such as organizing online training program to enhance undergraduates' learning as additional value to increase students' competencies. Research implications were further discussed.

Keywords: Online Learning, E-Learning, Undergraduate Malaysia, Training Program Effectiveness, Learning Performance, Education, Human Resource Development, Human Development, Education

\section{Introduction}

Pandemic COVID 19 is an infectious disease caused by a new novel virus named coronavirus that have been discovered from China and reported by WHO (World Health Organization) since December 2019 (Yuki, Fujiogi \& Koutsogiannaki, 2020). To date, more than 130 million people were infected causing almost three million death around the world (Coronavirus Cases, 2021, updated 3 April). This has alarmed people around the world to change the communication medium into online communication in order to prevent the spread of pandemic (Douglas, Katikireddi, Taulbut, McKee \& McCartney, 2020). As a result, it has impacted the way of people doing work, learn in school, run business, and socialization (Wolor et al., 2020). This has also impacted the world economy, education, health, politic, and social norms and performance (Baldwin \& di Mauro, 2020).

In educational context, previous researchers have been researching the effectiveness of online learning to replace traditional classroom in formal educational setting during pandemic COVID 19 especially among the school students (e.g., Radha, Mahalakshmi, Kumar \& Saravanakumar, 2020) as well as among undergraduates (e.g., Hergüner et al., 2021). Unfortunately, research reporting online learning effectiveness for informal educational setting have not received much attention (Mogboh, 2021); for example, research reporting the effectiveness of online learning to replace traditional classroom setting for training program among undergraduates during the pandemic has been neglected.

Instead of formal educational setting, informal education such as training program also plays important roles in developing students' competencies especially for those at university level (Estevez et al., 2018). This is because undergraduates need to be prepared with various competencies that are not provided in formal education, such as communication skills, selfmanagement skills, self-motivation, and other competencies that are needed for future job prospects (Aziz, 2016; Roca-Hurtuna et al., 2021). In fact, Baticulon et al. (2021) stressed that online learning will not always achieve its objective due to various obstacles, such as learning styles, learning environment and poor communication from teacher/instructor. Therefore, the aim of this article is to report whether online learning is effective to replace traditional classroom for training program during pandemic COVID 19 among undergraduates at university level using a quasi-experimental design.

\section{Literature Review}

Online learning is a learning experience that uses information technology to support distance learning with additional features in improved educational flexibility, connectivity, and ability of interactions through internet (Moore, Dickson-Deane \& Galyen, 2011, p.130). Since December 
2019, COVID 19 has impacted the world's economy, education, health, politic, and social norms and performance (Baldwin \& di Mauro, 2020). The most significant effect of COVID 19 is the used of online communication to prevent the spread of COVID 19 (Douglas et al., 2020; Baldwin \& di Mauro, 2020).

In educational context, online learning was also mandated as educational medium to replace traditional classroom or face-to-face education at school, colleges and university during pandemic COVID 19 (Mogboh, 2021). Therefore, various researches were done to improve the quality of online learning in formal educational setting (e.g., Almaiah, Al-Khasawneh \& Althunibat, 2020; Makarova, 2021; Hergüner et al., 2021). Unfortunately, research reporting online learning effectiveness for informal educational setting has not received much attention (Mogboh, 2021); for example, research reporting the effectiveness of online training program during the pandemic has been neglected. However, informal education such as training program also plays important roles in developing students' competencies especially for those at university level (Roca-Hurtuna et al., 2021).

Training program is actually a part of adult education that organized in most of working organizations (Aziz, 2018; Merriam \& Bierema, 2014). Fortunately, in order to provide knowledge and skills as well as to form positive attitude and value, the application of training program has been widely used in various levels of the society including for undergraduates (Aziz \& Selamat, 2018; Roca-Hurtuna et al., 2021). From theoretical perspectives, the theory of Social Cognitive by Bandura (1977) was usually adapted in developing a training program (Merriam \& Bierema, 2014). The theory of Social Cognitive suggests that human learns by the interaction of his/her personal attributes with environment and behaviors shown by other people as a role model (Bandura, 1977). This implies that human learns using their cognitive, psychology, and psychomotor to provide cognitive, skills and affective outcomes in training programs (Aziz, Silong \& Zakaria, 2018).

Consistently, the model of Learning Outcomes Evaluation for training programs by Kraiger, Ford and Salas (1993) explain that there are three main components of learning outcomes that should be evaluated to determine training effectiveness (see Figure 1); these include cognitive, skills and affective outcomes. These components are further explained as acquired knowledge, skills and self-efficacy attitude related to the training objectives in order to determine training effectiveness (Aziz et al., 2018). Therefore, to determine online training effectiveness, the knowledge, skills and self-efficacy attitude gained by participants should be measured. Additionally, according to Stehle, Spinath and Kadmon (2012) as well as Aziz and Selamat (2016), there is no differences if the learning outcomes are measured by examination/test or participant's self-perception because each measurement is from the same source of participant. This implies that instrument measuring training effectiveness from participant's perception, such as the General Training Effectiveness by Aziz (2015) can be adapted to measure learning performance among participants in online training program. 
Vol. 10, No. 2, 2021, E-ISSN: 2226-6348 @ 2021 HRMARS

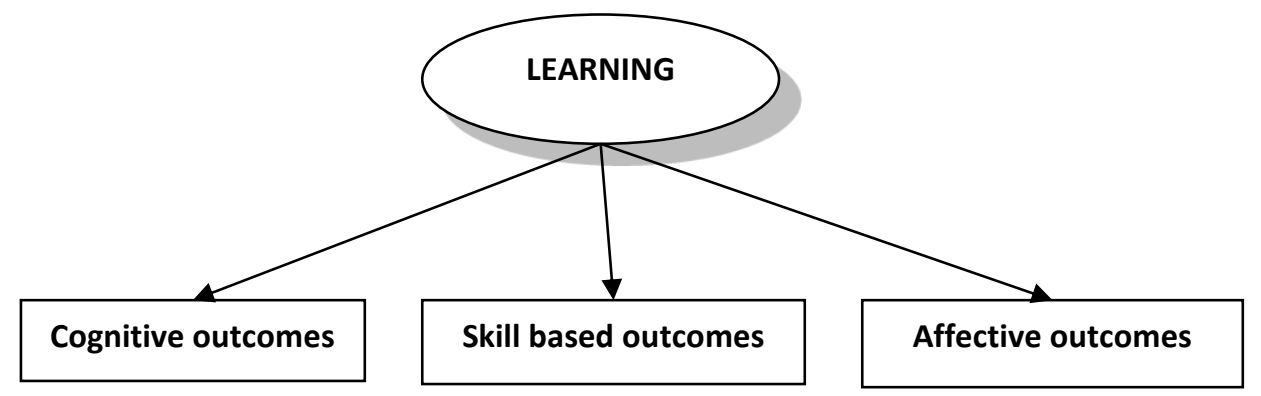

Figure 1: A Preliminary Classification Scheme of Learning Outcomes

(Source: Kraiger et al., 1993, pp. 312)

According to Aziz et al. (2018, p. 5068), individual knowledge, skills and self-efficacy attitude can be measured to determine individual learning related to the training program's objective in order to evaluate training effectiveness. The individual knowledge is defined as learning changes in declarative knowledge, procedural knowledge, and metacognition; meanwhile, the individual skill is defined as task accomplishment based on the list of psychomotor performance related to training objectives. Additionally, self-efficacy attitude is defined as the individual's willingness, desire, and strong confidence to perceive and behave accordingly (based on related training objectives). Hence, after the completion of training program, participants should have improvements in learning performance in terms of the knowledge, skills and self-efficacy attitude improvements; in which, there should be different scores of learning performance as measured before and after the completion of training.

Further, previous researches related to training program effectiveness among undergraduates at university level such as by Aziz (2016) found that training program among Malaysian undergraduates is needed to improve their skills in communication skills. In addition, Estevez et al. (2018) found that training program among undergraduates in Cuba is needed to improve their knowledge to prevent the misuse of alcohol. Additionally, Roca-Hurtuna et al. (2021) found training program has successfully changed attitude towards disable person among students at a university in Spain. These have shown that training programs are needed for undergraduates to improve their learning in specific competencies that are not taught in formal educational setting.

Furthermore, a small number of researches related to online learning effectiveness in formal educational setting among undergraduates, such as by Hergüner et al. (2021) found that online learning is effective for formal education during COVID 19. In contrast, a large number of researches, such as Almaiah et al. (2020) found that there were various obstacles in online learning used to replace traditional classroom for formal education during the pandemic, which finally resulted in ineffective online learning among undergraduates in Jordan and Saudi Arabia. The barriers include unaffordable technology, low quality of e-learning system, low self-efficacy, low trust in e-learning effectiveness, and time needed to adapt with the new norms of e-learning. In addition, Makarova (2021) found that online learning that has replaced the traditional education medium during the pandemic among Russian undergraduates majoring Economic and Management study was vulnerable for ineffective education due to the laziness and inability to concentrate among students. Additionally, Baticulon et al. (2021) found that online learning 
during COVID 19 among medical students at Philippines was ineffective due to several reasons including poor communication between lecturers and students, learning styles, and distraction of responsibilities given by parents at home. Hence, there are various barriers to online learning effectiveness that could also affect the effectiveness of training program among undergraduates if using online learning during the pandemic.

Therefore, two pair hypotheses are constructed to be tested at 0.05 significant level including hypothesis null $\left(\mathrm{H}_{0}\right)$ and hypothesis alternative $\left(\mathrm{H}_{\mathrm{a}}\right)$.

Pair 1:

$1 \mathrm{H}_{0}=$ There is no significant difference of learning performance scores as measured before and after the completion of online training program

$1 \mathrm{H}_{\mathrm{a}}=$ There is a significant difference of learning performance scores as measured before and after the completion of online training program

Pair 2:

$2 \mathrm{H}_{0}=$ There is no significant difference of learning performance among participants in different online training program with dissimilar training objective

$2 \mathrm{H}_{\mathrm{a}}=$ There is a significant difference of learning performance among participants in different online training program with dissimilar training objective

\section{Methodology}

A quasi-experimental design was used to achieve the research objective. Three open-registration for online training programs were organized among University Kebangsaan Malaysia's (UKM) undergraduate students in December 2021; the programs were free of fees and advertised through university's advertising channel and social media. These online training programs were organized by students registered for SKPM2093 subject (Training Management and Behavior Modification) as part of their group assignment with lecturer's supervision. The programs were also registered with UKM's formal portal for student activities named i-star, designed intensively with lecturer's supervision (the lecturer, Dr. Siti Fardaniah Abdul Aziz is a subject matter expert in Training Program Management that also plays role as one of the speakers), organized in one full day, delivered in Malay language, and combined several expert speakers related with the training objective.

The three training programs were:

(1) Program Motivasi Pelajar 2020 or Online Students Motivation Program 2020 (OSMP)

(2) Webinar Perniagaan Atas Talian or Online Business Webinar 2020 (OBW)

(3) Program atas Talian Mahasiswa Cemerlang: Terurus atau Diurus or Online Program for Excellent Undergraduates' Self-Management 2020 (EUSMOP)

The objective of OSMP is to provide students with learning motivation to stay motivated to learn during COVID 19. Four speakers were invited including a teacher from secondary school, a lecturer from UKM, an excellent student with high academic achievement from other university 
(UNISZA/ Universiti Sultan Zainal Abidin), and an excellent student that hold top management position in university association from other university (UUM/ University Utara Malaysia). The online training contents include communication confidence for students, learning strategy for high academic achievement, life planning and goals for students, and tips to achieve high academic achievement. A total of 18 participants attended the online training program.

Further, the objective of OBW is to provide students with business skills to generate incomes while being students during COVID 19. Three speakers were invited including a successful business student from UKM that already developed her own business in bakery, a lecturer from UKM, and a successful MLM supervisor which is also an undergraduate student. The online training contents include how to generate income as business agent and dropship, how to generate income through own business, and how to plan and start an online business. A total of 11 participants attended the online training program; participants were UKM's undergraduate students from various faculties in UKM.

Furthermore, the objective of EUSMOP is to provide students with self-management skills as university students to stay manageable during COVID 19. Five speakers were invited including a successful business man that is also a medical doctor that has several aesthetic clinic branches, a lecturer from UKM, a successful insurance agent, three higher achievers among undergraduates including two with top management position in student association, and one with high academic achievement. The online training contents include how to manage time schedule as university students, how to stay motivated and be successful in life, how to manage learning strategy for high academic achievement, how to manage financial, and how to balance the academic and cocurriculum in university life. A total of 23 participants attended the online training program; participants were UKM's undergraduate students from various faculties in UKM.

On the other hand, instrument used to measure learning performance was adapted from General Training Effectiveness Scale by Aziz (2015). Items were adapted into 15 items according to specific objectives for each online training program; in which, item number 1 to 5 represent knowledge acquisition, item number 6 to 10 represent skills acquisition, and item number 11 to 15 represent changes in self-efficacy attitudes. The questionnaires were constructed in Malay language and attached as google form that can be accessed by participants; participants need to answer the questionnaire before and after the completion of training. Participants need to determine their own learning performance as perceived before and after the completion of each online training program. They were 15 items in google form questionnaire; participants need to answer the questionnaire based on 10 scales; in which, scale 1 represent strongly disagreed, and scale 10 represents strongly agreed.

Sample item to measure knowledge learning in OSMP was "I learn something new in this training (Saya belajar sesuatu yang baru dalam kursus ini)", in OBW was "I learn new knowledge in this training (Saya belajar ilmu yang baru dalam kursus ini)", and in EUSMOP was "I acquired new information in this training (Saya memperoleh pengetahuan baru dalam kursus ini)". 
Vol. 10, No. 2, 2021, E-ISSN: $2226-6348$ @ 2021 HRMARS

Sample item to measure skills acquired in OSMP was "I have learning strategy after attending this training (Saya mempunyai strategi belajar setelah menghadiri kursus ini)", in OBW was "My skills about the subject taught in this training have improved (Kemahiran saya tentang perkara yang diajar dalam kursus ini telah bertambah.)", and in EUSMOP was "I have a strategy for time management after attending this training. (Saya mempunyai strategi pengurusan masa setelah menghadiri kursus ini.)".

Sample item to measure self-efficacy attitude changed in OSMP was "I am confident that I am more skilled for smart learning after attending this training. (Saya yakin saya lebih berkemahiran untuk belajar dengan bijak selepas menghadiri kursus ini)", in OBW was "I am confident that I am more skilled to sell after attending this training (Saya yakin saya lebih berkemahiran untuk menjual selepas menghadiri kursus ini)", and in EUSMOP was "I am confident that I am more skilled to be more productive after attending this training (Saya yakin saya lebih berkemahiran untuk menjadi lebh produktif selepas menghadiri kursus ini)",

Respondents attended the three online training programs were involved on the basis of voluntary participation and have given their consent to answer the questionnaire. They were also undergraduate students in UKM from various faculties and educational field of studies in UKM, such as from engineering, economy, management, science, social science, education, and Islamic studies educational background. In total, there were 52 respondents involved in the research as participants from these online training programs during December 2020.

Data were analyzed using SPSS (Statistical Package for Social Sciences) version 26 involving descriptive and inferential analysis. In descriptive analysis, the level of participants' learning achievement were analyzed; in which, the mean scores for questionnaire measuring learning performance as perceived by participants were recoded from 10 scores to 3 scores to determine the level of learning performance as follows:

i) scores 1 to 4 were recoded as Low level

ii) scores 4.1 to 7 were recoded as Medium level

iii) scores 7.1 to 10 were recoded as High level

Meanwhile, in inferential analysis, paired sample t-test was analyzed to test hypothesis 1 and to determine significant difference of participants' level of learning performance as measured before and after the completion of online training in order to verify their learning performance. In addition, one-way ANOVA was done to test hypothesis 2 and to determine online training effectiveness across different training programs with dissimilar objectives.

In addition, Alpha Cronbach reliability analysis for instrument used in this research indicate a good internal consistency for the 15 items as tested among the 52 respondents; in which it has Alpha Cronbach value of 0.967 for Online Students Motivation Program 2020 (OSMP) with 18 participants, 0.974 for Online Business Webinar 2020 (OBW) with 11 participants, and 0.944 for Online Program for Excellent Undergraduates' Self-Management 2020 (EUSMOP) with 23 participants. 


\section{Findings and Discussion}

Findings indicated that the level of learning performance for each training program is high for majority of respondents. In addition, learning performance in all three different online training programs among participants were effective based on significant mean differences for scores as measured before and after the completion of training using paired sample t-test. Additionally, there is no significant difference between the level of learning performance among respondents between the three groups of online training programs after the completion of training; this indicates that online training program is effective to increase undergraduates' learning performance regardless the training objectives.

\section{The level of Learning Performance}

After the completion of online training, majority of participants in all the online training programs have perceived the level of learning performance has increased to a high level; in which, $100 \%$ participants in EUSMOP and OBW perceived it as high, and $88.9 \%$ participants in OSMP perceived it as high (see Figure $2 a$, Figure $2 b$ and Figure $2 c$ ). This has verified that the level of learning performance for respondents in each online training program was high after the completion of online training. This is consistent with previous research by Aziz (2016), Estevez et al. (2018) and Roca-Hurtuna et al. (2021) that demonstrated the importance of training program to increase the level of learning among undergraduates in developing specific competencies; however, the previous training programs were organized using traditional classroom setting. In addition, findings also consistent with Hergüner's et al. (2021) research that online learning is effective to replace traditional classroom; however, the research was done using sample from formal education among undergraduates. Therefore, the current research has verified that online learning is effective to increase the level of learning performance among participants attended training program as informal education.



Figure 2a: The level of Learning among participants in Online Students Motivation Program 2020 (OSMP) 
INTERNATIONAL JOURNAL OF ACADEMIC RESEARCH IN PROGRESSIVE EDUCATION AND DEVELOPMENT

Vol. 10, No. 2, 2021, E-ISSN: 2226-6348 @ 2021 HRMARS

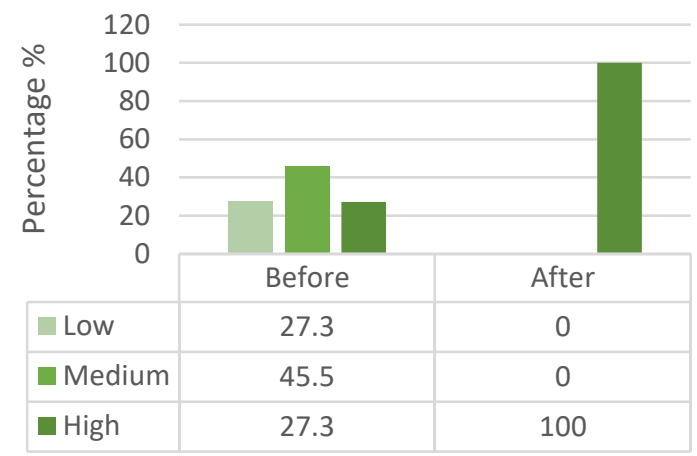

Figure 2b: The level of Learning among participants in Online Business Webinar 2020 (OBW)

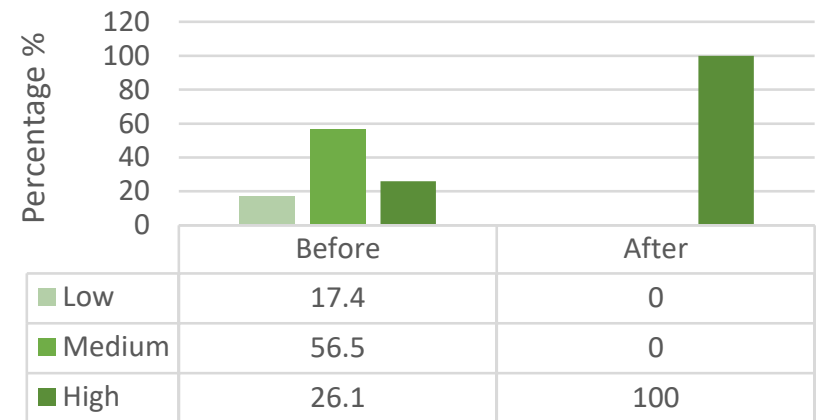

Figure 2c: The level of Learning among participants in Online Program for Excellent Undergraduates' Self-Management 2020 (EUSMOP)

\section{Comparison of Learning Performance as Measured Before and after The Completion of Online} Training Programs

Comparison test using paired sample t-test was done to determine learning changes among respondents. Table 1 and Table 2 represents the results of paired sample t-test for each online training program as measured before and after the completion of training. Meanwhile, Figure 3 shows the mean scores for participants' perceived learning performance as measured before and after the completion of training. Findings indicate that there was a significant difference between the mean scores as measured before and after the completion of all online training programs. This implies an improvement in leaning performance.

For the OSMP, there was significant improvements before $(M=5.9556, S D=2.17580)$ and after the completion of OSMP (M = 8.5852, SD = 1.20967) with the change of $t(17)=5.117, p<0.000$ (two-way). The increase in mean scores was 2.6296 with $95 \%$ confidence interval for the difference between 1.54535 and 3.71391. Using the formula by Cohen (1988, pp. 284-7) and Pallant (2013), the eta-squared statistic shows a large effect size (0.5926).

Further, for the OBW, there was significant improvements before $(M=5.2727, S D=2.33723)$ and after the completion of OBW $(M=8.9152, S D=0.91898)$ with the change of $t(10)=5.255, p$ $<0.000$ (two-way). The increase in mean scores was 3.6425 with $95 \%$ confidence interval for the 
INTERNATIONAL JOURNAL OF ACADEMIC RESEARCH IN PROGRESSIVE EDUCATION AND

DEVELOPMENT

Vol. 10, No. 2, 2021, E-ISSN: 2226-6348 @ 2021 HRMARS

difference between 2.09817 and 5.18668. Using the formula by Cohen (1988, pp. 284-7) and Pallant (2013), the eta-squared statistic shows a large effect size (0.7151).

Furthermore, for the EUSMOP, there was significant improvements before $(M=5.7507, S D=$ 2.04537) and after the completion of EUSMOP ( $M=8.8725, S D=0.90630)$ with the change of $t(22)=6.624, p<0.000$ (two-way). The increase in mean scores was 3.1218 with $95 \%$ confidence interval for the difference between 2.14435 and 4.09913. Using the formula by Cohen (1988, pp. 284-7) and Pallant (2013), the eta-squared statistic shows a large effect size (0.6560).

Table 1. Paired Sample Statistics

\begin{tabular}{|c|c|c|c|c|c|}
\hline & & Mean & $\mathrm{N}$ & $\begin{array}{l}\text { Standard } \\
\text { Deviation }\end{array}$ & $\begin{array}{c}\text { Standard Deviation } \\
\text { Error }\end{array}$ \\
\hline \multicolumn{6}{|c|}{ Online Students Motivation Program 2020 (OSMP) } \\
\hline \multirow[t]{2}{*}{ Pair 1} & After & 8.5852 & 18 & 1.20967 & .28512 \\
\hline & Before & 5.9556 & 18 & 2.17580 & .51284 \\
\hline \multicolumn{6}{|c|}{ Online Business Webinar 2020 (OBW) } \\
\hline \multirow[t]{2}{*}{ Pair 2} & After & 8.9152 & 11 & 0.91898 & .27708 \\
\hline & Before & 5.2727 & 11 & 2.33723 & .70470 \\
\hline \multicolumn{6}{|c|}{ Online Program for Excellent Undergraduates' Self-Management 2020 (EUSMOP) } \\
\hline \multirow[t]{2}{*}{ Pair 3} & After & 8.8725 & 23 & 0.90630 & .18898 \\
\hline & Before & 5.7507 & 23 & 2.04537 & .42649 \\
\hline
\end{tabular}

Table 2. Paired Sample Test

$\begin{array}{ccccccc}\text { Mean } & \begin{array}{c}\text { Standard } \\ \text { Deviation }\end{array} & \begin{array}{c}\text { Standard } \\ \text { Deviation } \\ \end{array} & \begin{array}{c}\text { 95\% Confidence } \\ \text { Interval of the }\end{array} & \text { t } & \text { df } & \begin{array}{c}\text { Sig. } \\ (2-\end{array} \\ & & & & \text { way) } \\ & & \text { Lower } \quad \text { Upper } & & \end{array}$

Online Students Motivation Program 2020 (OSMP)

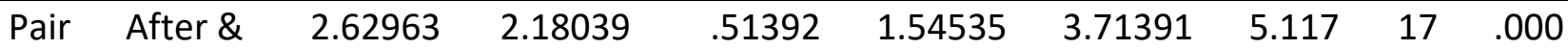

1 Before

Online Business Webinar 2020 (OBW)

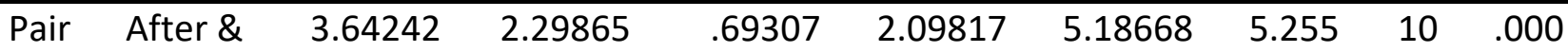

2 Before

Online Program for Excellent Undergraduates' Self-Management 2020 (EUSMOP)

$\begin{array}{llllllllll}\text { Pair } & \text { After \& } & 3.12174 & 2.26021 & .47129 & 2.14435 & 4.09913 & 6.624 & 22 & .000\end{array}$

3 Before 
Vol. 10, No. 2, 2021, E-ISSN: 2226-6348 @ 2021 HRMARS

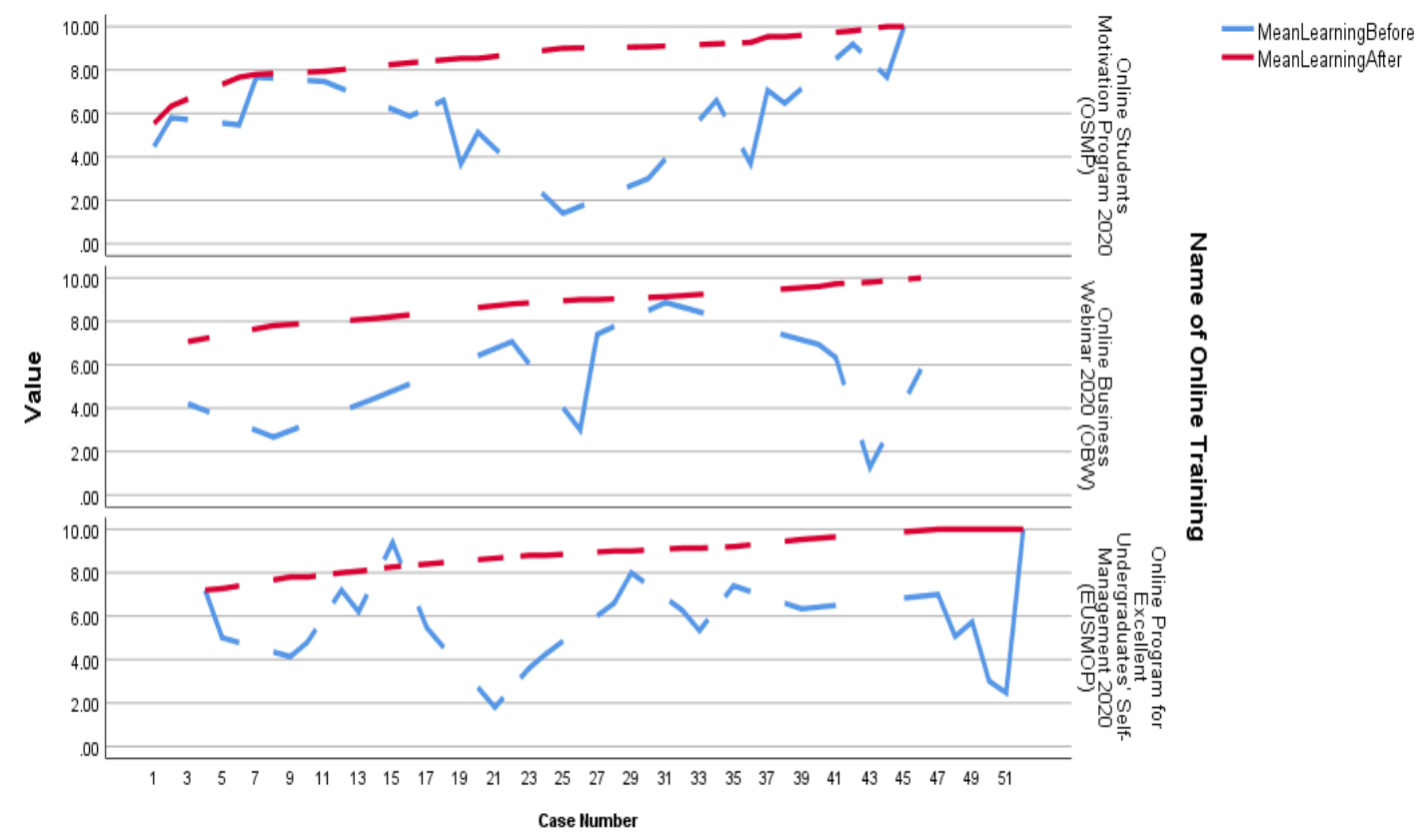

Figure 3: Mean scores for participants' perceived learning performance as measured before and after the completion of training

Therefore, hypothesis $1 \mathrm{H}_{0}$ is rejected and hypothesis $1 \mathrm{H}_{\mathrm{a}}$ is fully accepted indicating that there is a significant difference of learning performance scores as measured before and after the completion of online training program for each training program. Finding is consistent with researches done by Aziz (2016) and Estevez et al. (2018) that found significant difference of learning among participants as measured before and after the completion of training program indicating effective training program among undergraduates. However, the different between current research and previous researches is the current research found and highlighted that not only traditional classroom for training program can be effective, online training program among undergraduates during pandemic COVID 19 can also be effective. Hence, online training program should be organized during pandemic to support additional knowledge, skills, competencies and values that are not covered in formal educational setting among undergraduates.

Interestingly, finding is inconsistent with research by Almaiah et al. (2020), Makarova (2021), and Baticulon et al. (2021) that found the replacement of online learning for traditional classroom setting in formal education is ineffective due to various barriers. Perhaps, the structure of training program as informal education is different from the structure of formal education resulting effective online learning to replace traditional classroom for training program but not to replace most of formal education among undergraduates.

The Comparison of Learning Performance Across Different Online Training Programs' Objective A one-way ANOVA test was done to determine whether there are any significant differences between learning performance perceived by participants for each online training with dissimilar training objectives. Results demonstrated an insignificant difference for the one-way ANOVA; 
these implies that all the online training programs have increase learning among participants regardless the different training objectives.

Table 3 and Table 4 shows the results of one-way ANOVA. Results indicated no significant difference between the three online training programs that have different objectives; in which, $F(2,49)=0.515, p=.601$, suggesting no differences in the effectiveness of the three online training programs. Hence, hypothesis $2 \mathrm{H}_{0}$ is fail to be rejected and hypothesis $2 \mathrm{H}_{\mathrm{a}}$ is rejected indicating that there is no significant difference of learning performance among participants in different online training programs. This has verified that online learning used for training programs among undergraduates is effective across different training objectives.

Finding is also consistent with research by Aziz (2016), Estevez et al. (2018) and Roca-Hurtuna et al. (2021) that demonstrated the importance of training program to increase the level of learning among undergraduates in developing specific competencies. Finding also strengthen the fact that online learning can be used to organize training program among undergraduates during pandemic COVID 19. Hence, online training program should be organized during pandemic to support additional knowledge, skills, competencies and values that are not covered in formal educational setting among undergraduates.

Table 3. One-way ANOVA Test

\begin{tabular}{lccccc}
\hline & $\begin{array}{c}\text { Sum of } \\
\text { Squares }\end{array}$ & df & $\begin{array}{c}\text { Mean } \\
\text { Square }\end{array}$ & F & Sig. \\
\hline Between Groups & 1.080 & 2 & .540 & .515 & .601 \\
Within Groups & 51.392 & 49 & 1.049 & & \\
\hline Total & 52.472 & 51 & & & \\
\hline
\end{tabular}


Vol. 10, No. 2, 2021, E-ISSN: 2226-6348 @ 2021 HRMARS

Table 4. Descriptive One-way ANOVA statistics

\begin{tabular}{|c|c|c|c|c|c|c|c|c|}
\hline & \multirow[t]{2}{*}{$\mathrm{N}$} & \multirow[t]{2}{*}{ Mean } & \multirow[t]{2}{*}{$\begin{array}{c}\text { Std. } \\
\text { Deviation }\end{array}$} & \multirow[t]{2}{*}{$\begin{array}{l}\text { Std. } \\
\text { Error }\end{array}$} & \multicolumn{2}{|c|}{$\begin{array}{l}\text { 95\% Confidence } \\
\text { Interval of the } \\
\text { Difference }\end{array}$} & \multirow[t]{2}{*}{ Minimum } & \multirow[t]{2}{*}{ Maximum } \\
\hline & & & & & Lower & Upper & & \\
\hline $\begin{array}{l}\text { Online Students } \\
\text { Motivation } \\
\text { Program } 2020 \\
\text { (OSMP) }\end{array}$ & 18 & 8.5852 & 1.20967 & .28512 & 7.9836 & 9.1867 & 5.53 & 10.00 \\
\hline $\begin{array}{l}\text { Online Business } \\
\text { Webinar } 2020 \\
\text { (OBW) }\end{array}$ & 11 & 8.9152 & .91898 & .27708 & 8.2978 & 9.5325 & 7.07 & 10.00 \\
\hline $\begin{array}{l}\text { Online Program } \\
\text { for Excellent } \\
\text { Undergraduates' } \\
\text { Self- } \\
\text { Management } \\
2020 \text { (EUSMOP) }\end{array}$ & 23 & 8.8725 & .90630 & .18898 & 8.4806 & 9.2644 & 7.20 & 10.00 \\
\hline Total & 52 & 8.7821 & 1.01433 & .14066 & 8.4997 & 9.0644 & 5.53 & 10.00 \\
\hline
\end{tabular}

\section{Research Implication}

Findings of the current research indicated that online learning is effective and suitable to replace traditional classroom setting for training program among undergraduates during pandemic COVID 19. Hence, there are several implications especially to educational field of study among undergraduates. First, online learning should be used not only in formal education but also in informal education, such as training program among undergraduates because it is effective to replace traditional classroom during the pandemic. This is important because most of previous researchers including Aziz (2016), Estevez et al. (2018), and Roca-Hurtuna et al. (2021) found that training program is important to equip students with additional competencies that were not taught in formal education, such as to prepare them with future job needs. Hence, online training program should be organized to support additional knowledge, skills, competencies and values that are not covered in formal educational setting among undergraduates during pandemic. Meanwhile, Chung and Mathew (2020) find that online learning satisfaction was a significant predictor for the continues used of online learning in education. This implies that the main step to improve online learning effectiveness is to organize online training program that can nurture positive attitude among undergraduates towards the use of online learning in education.

Second, the online training programs used in the current research were effective; however, it does not mean that any online training program will be effective. This is because those training programs used in the current research were planned and organized under a supervision of subject matter expert in Training Management field of study. According to Roca-Hurtuna et al. (2021) pedagogical strategy is an important characteristic to be included in effective training 
program among undergraduates. Meanwhile, Estevez et al. (2018) stressed the importance of fruitful knowledge and skills contents to be included in effective training program among undergraduates. In addition, Ang, Jedi and Lohgheswary (2021) find that the quality and accessibility of the online learning was important criteria of acceptance among undergraduates in technical courses. Soh, Lim, Yee, Ying and Yin (2018) find that online learning should stimulate active participation to improve learning effectiveness. Additionally, Alsubhi, Sahari and Wook, (2020) find that online learning should be added with interesting feature like games to attract the new generation of undergraduates. Unfortunately, research reporting characteristic of effective online training program among undergraduates during the pandemic has not been reported yet. Hence, characteristics of effective online training programs should be investigated further specifically among students at higher education level during the pandemic. Then, these characteristics can be used to organize effective online training programs in the future.

Third, according to Aziz (2016), there are various reasons affecting effective training program among undergraduates; in which, the main reason is training motivation or learning motivation among participants. Interestingly, from perspective of online training program among adult employees, most of researchers including Moradi, Yahya, Mohamed and Raisian (2017), and Shahzadi and Ali (2021) find that e-learning motivation was the most important criteria affecting online training effectiveness. In fact, factors affecting effective training program should be provided to stimulate training motivation, such as by providing encourage learning environment, improve lecturer/trainer quality, and designing effective training program (Aziz, 2016; Aziz \& Selamat, 2016; Garavan et al., 2021). Meanwhile et al (2020) find that undergraduates in a Malaysian university had high level of readiness to use online learning during COVID 19, unfortunately their level of motivation to learn was only moderate. This implies that characteristics of effective online training programs should be pointed to trigger the e-learning or online training motivation in order to stimulate and maximized the effectiveness of online training program among undergraduates.

Fourth, various researchers, such as Almaiah et al (2020); Makarova (2021); Baticulon et al. (2021) have reported that most of online learning used to replace traditional classroom for formal education among undergraduates were ineffective during the pandemic due to various barriers. Only small number of researches, such Hergüner et al. (2021) found that online learning among undergraduates was effective in formal education. Interestingly, Hergüner's et al. (2021) research found that students' attitude towards online learning was the main reason affecting effective online learning in replacing traditional classroom for formal education; this demonstrated that the main reason of effective online learning is actually students' motivation for online learning. Therefore, the characteristics of effective online training program that stimulate motivation to learn should be investigated further to be used and adapted as intervention in improving online learning for formal education.

Finally, various researchers, such as Almaiah et al. (2020); Makarova (2021); Baticulon et al. (2021) have reported that barriers affecting ineffective online learning used to replace traditional classroom in formal education were factors related to insufficient knowledge, skills and self- 
efficacy attitude to use online learning effectively in both students and lecturers; these include, the low self-efficacy, low trust in e-learning effectiveness, insufficient skills to adapt with the new norms of e-learning, laziness and inability to concentrate, poor communication between lecturers and students, unsuitable learning styles, and distraction of responsibilities given by parents at home. Therefore, online training program should be organized frequently as a solution to fulfil those insufficient competencies. In fact, Hussien et al (2020) have adapted the concept of training organization to equip undergraduates with specific formal education content; in which, a one-stop online learning plagiarism module was built to train undergraduates with continuous learning using online platform.

In addition, online training program is not only beneficial to undergraduates but also to lecturers (Khalid et al., 2014). This is because some researchers including Baticulon et al. (2021) find that lecturers' lack of competencies in using online learning was among the reason of ineffective online learning used in formal education. Hence, online training program should be organized either as normal training or training for trainer program. Normal training program is used to train participant directly and suitable to target small number of participants; meanwhile, training for trainer program is suitable to target a large number of participants because it trains key-person as training participant so that the key-person will be able to play role as trainer in the future to deliver and spread the taught competencies among other group of participants (Kopf \& Kreuze, 1991; Huang, Licatino \& Sims 2021).

\section{Conclusion}

The pandemic COVID 19 has changed the way of people doing work, learn in school, run business, and socialization (Wolor et al., 2020). The most significant change is when people around the world have been changing communication medium to online communication in order to prevent the spread of disease (Douglas et al., 2020). This has impacted the world economy, education, health, politic, social norms and performance (Baldwin \& di Mauro, 2020). From educational perspective, previous researchers have been researching the effectiveness of online learning as a communication medium to replace traditional classroom in formal educational setting either at school or university level (e.g., Radha et al., 2020; Hergüner's et al., 2021). Unfortunately, research reporting online learning effectiveness for informal educational setting have not received much attention (Mogboh, 2021); for example, research reporting the effectiveness of online training program among undergraduates during the pandemic has been neglected. Therefore, the aim of this article was to determine the effectiveness of online training program for undergraduates using a quasi-experimental design. Findings indicated that the level of learning in online training programs among undergraduates have increased after training completion regardless dissimilar training objectives. This has major implication for the use of online learning in informal education, in which it should be used to replace traditional classroom setting for training program among undergraduates during the pandemic. In fact, online training program should be organized frequently during pandemic to support additional knowledge, skills, competencies and values that are not covered in formal educational setting among undergraduates. Additionally, factors affecting effective online training program should be 
Vol. 10, No. 2, 2021, E-ISSN: 2226-6348 @ 2021 HRMARS

investigated further as a guideline in organizing effective online training program as well as to improve ineffective online learning for most of formal education among undergraduates.

\section{Acknowledgement}

Special thanks to Universiti Kebangsaan Malaysia that supported the research under Strategic Action Research Grant (PTS-2013-047) as extension study and Encouragement Research Grant (GGP-2020-028).

\section{References}

Almaiah, M. A., Al-Khasawneh, A., \& Althunibat, A. (2020). Exploring the critical challenges and factors influencing the E-learning system usage during COVID-19 pandemic. Education and Information Technologies, 25, 5261-5280.

Alsubhi, M. A., Sahari, N., \& Wook, T. T. (2020). A conceptual engagement framework for gamified e-learning platform activities. International Journal of Emerging Technologies in Learning, 15(22), 4-23.

Ang, W., Jedi, A., \& Lohgheswary, N. (2021). Factors affecting the acceptance of open learning as e-learning platform by technical course students. Journal of Engineering Science and Technology, 16(2), 903-918.

Aziz, S. F. A. (2015). Developing General Training Effectiveness Scale for the Malaysian Workplace Learning. Mediterranean Journal of Social Sciences, 6(4), 47-56.

Aziz, S. F. A. (2016). Lecturer Quality as Teaching and Learning Intervention. In R. M. K. Nambiar, N. F. M. Nor \& M. Z. Sulaiman (Eds.), Action Research: A window to new experiences in teaching and learning. Bangi, Selangor: Penerbit UKM.

Aziz, S. F. A. (2018). Keberkesanan latihan dan pembangunan sumber manusia. Bangi, Selangor: Penerbit UKM.

Aziz, S. F. A., \& Selamat, M. N. (2016). Stimulating workplace learning through training characteristics and motivation to learn. Jurnal Pengurusan, 48, 173-185.

Aziz, S. F. A., Silong, A. B., \& Zakaria, Z. (2018). Developing Individual Training Impact Scale for workplace training: Testing the Malaysian sample to determine the impact of training on individual effectiveness. Advanced Science Letters, 24, 5067-5069.

Baldwin, R., \& Di Mauro, B. W. (2020). Introduction. In R. Baldwin, \& B. W. di Mauro (Eds). Economics in the time of COVID-19. Economics in the Time of COVID-19, (pp.1-30). London: CER Press.

Bandura, A. (1977). Social learning theory. In Miltenberger, R. G. (2016). Behavior modification: Principles and procedures ( 6 ed.). Belmont, USA: Cengage Learning.

Baticulon, R. E., Sy, J. J., Alberto, N. R. I., Baron, M. B. C., Mabulay, R. E. C., Rizada, L. G. T., Tiu, C. J., Clarion, C. A., \& Reyes, J. C. B. (2021). Barriers to online learning in the time of COVID19: A national survey of medical students in the Philippines. Medical Science Educator, Online first, https://doi.org/10.1007/s40670-021-01231-z.

Chung, E., Noor, N. M., \& Mathew, V. N. (2020). Are you ready? An assessment of online learning readiness among university students. International Journal of Academic Research in Progressive Education and Development, 9(1), 301-317. 
Chung, E., \& Mathew, V. N. (2020). Satisfied with online learning amidst COVID-19, but do you intend to continue using it? International Journal of Academic Research in Progressive Education and Development, 9(4), 67-77.

Coronavirus Cases. (2021). Retrieved 3 April 2021, 2021, from https://www.worldometers.info/coronavirus/

Douglas, M., Katikireddi, S. V., Taulbut, M., McKee, M., \& McCartney, G. (2020). Mitigating the wider health effects of covid-19 pandemic response. BMJ, 369, https://doi.org/10.1136/bmj.m1557.

Estevez, A. G., Roche, J. R. F., Espinosa, A. H. R., \& Rodríguez, D. L. (2018). Social skills training program to prevent alcohol consumption in university students. International Journal of Health Sciences, 2(3), 43-54.

Garavan, T., McCarthy, A., Lai, Y., Murphy, K., Sheehan, M., \& Carbery, R. (2021). Training and organisational performance: A meta-analysis of temporal, institutional and organisational context moderators. Human Resource Management Journal, 31(1), 93-119.

Hergüner, G., Yaman, Ç., Sari, S. Ç., Yaman, M. S., \& Dönmez, A. (2021). The effect of online learning attitudes of sports sciences students on their learning readiness to learn online in the era of the New Coronavirus Pandemic (COVID-19). Turkish Online Journal of Educational Technology, 20(1), pp.68-77.

Huang, J., Licatino, L., \& Sims III, C. R. (2021). Training the Trainer: Preparing Anesthesiology Residents to be Trainers in the Operating Room. MedEdPORTAL, 17, 11116.

Hussien, H. S., Khalid, F., Hussin, S., Baharuddin, D. F., \& Rahman, A. (2020). Critical review of design and development of one-stop e-learning plagiarism module for an academic writing course: an application of the ICCEE model. Journal of Critical Reviews, 7(5), 1039-1048.

Khalid, S., Mohd, T. M. T., Hassanah, K., Sanip, S., Aris, M. S., Sharif, K., \& Mokthar, M. (2014). Elearning readiness among medical educators in Universiti Sains Islam Malaysia. American Journal of Applied Sciences, 11(1), 17-23.

Kraiger, K., Ford, J. K., \& Salas, E. (1993). Application of cognitive, skill-based, and affective theories of learning outcomes to new methods of training evaluation. Journal of Applied Psychology, 78(311-328).

Kopf, J. M., \& Kreuze, J. G. (1991). Achieving performance excellence: Training the trainer. American Journal of Business, 6(1), pp.23-26.

Makarova, E. (2021). Effectiveness of traditional and online learning: comparative analysis from the student perspective. SHS Web of Conferences (Vol. 99, p. 01019), EDP Sciences. https://doi.org/10.1051/shsconf/20219901019.

Merriam, S. B., \& Bierema, L. L. (2014). Adult Learning: Linking Theory and Practice. San Francisco, CA: John Wiley \& Sons.

Mogboh, V. E. (2021). Development of E-Learning Design Strategies towards Effectives University Smart Learning Environment. IOSR Journal of Research \& Method in Education (IOSR-JRME), 11(2), 1-7.

Moore, J. L., Dickson-Deane, C., \& Galyen, K. (2011). e-Learning, online learning, and distance learning environments: Are they the same? The Internet and Higher Education, 14(2), 129135. 
Moradi, L., Yahya, Y., Mohamed, I., \& Raisian, K. (2017). E-learning System Acceptance Factors for Training: A Study of Employees Perception in Tourism Industry. Journal of Environmental Management \& Tourism, 8(6 (22), 1250-1258.

Radha, R., Mahalakshmi, K., Kumar, V. S., \& Saravanakumar, A. R. (2020). E-Learning during lockdown of Covid-19 pandemic: A global perspective. International Journal of Control and Automation, 13(4), 1088-1099.

Roca-Hurtuna, M., Martinez-Rico, G., Sanz, R., \& Alguacil, M. (2021). Attitudes and work expectations of university students towards disability: Implementation of a training programme. International Journal of Instruction, 14(2), 1-10.

Shahzadi, I., \& Ali, U. (2021). Mediation of e-learner's achievement: a structural model on enablers of motivation for skill transfer in job-holder e-learners of Pakistan. Pakistan Journal of Distance and Online Learning, 6(2), pp.49-47.

Soh, O.-K., Lim, L.-A. D., Yee, L. Y., Ying, L. K., \& Yin, L. L. (2018). A review on the students' perceptions of online learning tools in improving English writing skills. International Journal of Academic Research in Progressive Education and Development, 7(4), 324-348.

Stehle, S., Spinath, B., \& Kadmon, M. (2012). Measuring teaching effectiveness: Correspondence between students' evaluations of teaching and different measures of student learning. Research in Higher Education, 53, 888-904.

Yuki, K., Fujiogi, M., \& Koutsogiannaki, S. (2020). COVID-19 pathophysiology: A review. Clinical Immunology, 108427.

Wolor, C. W., Solikhah, S., Fidhyallah, N. F., \& Lestari, D. P. (2020). Effectiveness of E-Training, ELeadership, and Work Life Balance on Employee Performance during COVID-19. The Journal of Asian Finance, Economics and Business, 7(10), 443-450. 